\title{
KEBERSIHAN MULUT DAN KONDISI JARINGAN PERIODONTAL PENDERITA DIABETES MELITUS DI PUSKESMAS KOTA TASIKMALAYA
}

\section{CLEAN AND PERIODONTAL NETWORK CONDITION OF DIABETES MELITUS PATIENTS IN PUSKESMAS KOTA TASIKMALAYA}

\author{
Culia Rahayu ${ }^{1^{*}}$, Yayah Sopianah ${ }^{2}$ \\ 1,2 Jurusan Keperawatan Gigi, Poltekkes Kemenkes Tasikmalaya \\ "culiarahayu@yahoo.com
}

\begin{tabular}{l}
\hline \\
\hline Kata kunci: \\
Diabetes Melitus \\
Kebersihan Mulut \\
Kondisi Jaringan Periodontal
\end{tabular}

ABSTRAK

Diabetes melitus adalah suatu penyakitkronik yang bersifat kompleks akibat gangguanmetabolisme karbohidrat karena kekuranganinsulin absolut atau relatif yang ditandai adanyakadar gula darah yang lebih tinggi dari normal. Pada penyakit diabetes mellitusyang tidak terkontrol terdapat beberapa komplikasi berupa gigi mudah goyang, gingivitis dengan pendarahan, periodontitis, pengendapan kalkulus yang cepat, kandidiasis, dan peningkatan risiko karies. Penelitian ini bertujuan untuk mengetahui kebersihan mulut dan kondisi jaringan periodontal pada penderita diabetes melitus di Puskesmas Kota Tasikmalaya. Jenis penelitian ini adalah penelitian kasus kontrol.Sampel penelitian ini berjumlah 40 orangpenderita periodontitis dan 40orang non periodontitis Pasien di Puskesmas Kota Tasikmalaya. Analisis data menggunakan uji statistik Chi Square dengan taraf signifikan $\alpha<$ 0,05 dengan tingkat kepercayaan 95\%. Hasil penelitian menunjukkan bahwa tidak ada perbedaan kebersihan mulut pada penderita diabetes mellitus dengan non diabetes mellitus. Terdapat perbedaan kodisi jaringan periodontal pada penderita diabetes mellitus dengan non diabetes mellitus. Penderita diabetes mellitus memiliki risiko mengalami periodontitis 4 kali dibandingkan dengan penderita non diabetes mellitus.

Key word:

Diabetes mellitus

Oral Hygiene

Periodontal Tissue Conditions

\section{ABSTRACT}

Diabetes mellitus is a chronic disease that is complex due to carbohydrate metabolism disorders due to absolute or relative insulin deficiency that is characterized by a higher than normal blood sugar level. In uncontrolled diabetes mellitus there are several complications in the form of loose teeth, gingivitis with bleeding, periodontitis, rapid deposition of calculus, candidiasis, and increased risk of caries. This study aims to determine oral hygiene and periodontal tissue conditions in people with diabetes mellitus in the Tasikmalaya City Health Center. This type of research is a case control study. The sample of this research is 40 people with periodontitis and 40 patients with non periodontitis in Tasikmalaya City Health Center. Data analysis used Chi Square 
statistical test with a significance level of $\alpha<0.05$ with a confidence level of $95 \%$. The results showed that there was no difference in oral hygiene in people with diabetes mellitus and non-diabetes mellitus. There are differences in periodontal tissue conditions in people with diabetes mellitus and non-diabetes mellitus. People with diabetes mellitus have a risk of experiencing periodontitis 4 times compared with patients with non diabetes mellitus.

\section{PENDAHULUAN}

Tantangan pembangunan kesehatan dan permasalahan pembangunan kesehatan makin bertambah berat, kompleks, dan bahkan tidak terduga. Pembangunan kesehatan dilaksanakan dengan memperhatikan dinamika kependudukan, epidemiologi penyakit, perubahan ekologi dan lingkungan, kemajuan ilmu pengetahuan dan teknologi, serta globalisasi dan demokratisasi dengan semangat kemitraan, kerja sama lintas sektoral serta mendorong peranserta aktif masyarakat (Kemenkes, 2011).

World Health Organization (WHO) pada tahun 2003 menyatakan Global Goals Oral Health 2020 yaitu meminimalkan dampak dari penyakit mulut dan kraniofasial dengan menekankan pada upaya promotif dan mengurangi dampak penyakit sistemik yang bermanifestasi di rongga mulut dengan diagnosa dini, pencegahan dan manajemen yang efektif untuk penyakit sistemik (Kemenkes, R.I, 2012). Penyelenggaraan kesehatan gigi dan mulut bertujuan untuk memelihara dan meningkatkan derajat kesehatan masyarakat dalam upaya peningkatan kesehatan gigi, pencegahan terjadinya penyakit gigi, pengobatan gigi, pemulihan kesehatan gigi (Kemenkes, R.I.,2012).

Diabetes mellitus adalah suatu penyakit kronik yang bersifat kompleks akibat gangguan metabolisme karbohidrat karena kekurangan insulin absolut atau relatif yang ditandai adanyakadar gula darah yang lebih tinggi dari normalatau di sebut dengan istilah hiperglikemia (Perry, DJ, dkk., 2007).

Pada pasien diabetes melitus terjadi perubahan di rongga mulut yang berhubungan dengan pengaruh diabetesnya. Perubahan itu diantaranya adalah mulut kering, lidah yang kotor, dan fissura-fissura yang terasa nyeri. Akibat lainnya adalah terjadi penurunan derajat keasaman ludah yang menyebabkan peningkatan jumlah bakteri di dalam mulut (Soeatmadji, 2000; Amerongen, 1991). Pada penyakit diabetes mellitusyang tidak terkontrol terdapat beberapa komplikasi berupa gigi mudah goyang, gingivitis dengan pendarahan, pengendapan kalkulus yang cepat, kandidiasis, dan peningkatan risiko karies (Suyono, et.al, 2006).

Periodontitis merupakan salah satu dari enam komplikasi diabetes melitus. Pada sejumlah penelitian menunjukkan bahwa keparahan penyakit periodontal meningkat pada penderita diabetes dibandingkan pada individu yang sehat (Matthew DC, 2002). Beberapa peneliti menyatakan bahwa keparahan penyakit periodontal pada penderita diabetes melitus dipengaruhi oleh penurunan respon imun. Kondisi tersebut ditandai terjadinya sejumlah perubahan jaringan yang menyebabkan kerentanan terhadap penyakit. Perubahan vaskuler yang terjadi menunjukkan adanya peningkatan aktifitas kolagen serta perubahan respon dan kemotaksis dari PMN terhadap antigen plak, sehingga menyebabkan fagositosis terhambat (Manson, J, 1993).

Penelitian yang hampir sama yaitu penelitian Rikawarastuti, dkk., (2015) menunjukkan pada penderita diabetes melitus lebih berisiko mengalami penyakit periodontal dibandingkan dengan non diabetes melitus, sedangkan hasil penelitian Sari, 
dkk., (2017) menunjukkan bahwa penyakit periodontitis pada penderita diabetes melitus cukup tinggi $(88,2 \%)$. Penelitian ini dibandingkan penelitian sebelumnya, selain memeriksa derajat kebersihan mulut (Hygiene Indeks),juga memeriksa kondisi jaringan periodontal dengan tingkatan mulai dari sehat, adanya perdarahan, karang gigi, poket dangkal dan poket dalam. Pada tahun 2018 prevalensi diabetes melitus di Kota Tasikmalaya sebanyak 2.135 orang (Dinas Kesehatan Kota Tasikmalaya, 2018). Kota Tasikmalaya terdiri dari 10 Kecamatan, yaitu : Kecamatan Indihiang, Cipedes, Mangkubumi, Kawalu, Cibeureum, Tawang, Cihideung, Tamansari, Purbaratu, dan Bungursari memiliki luas 183,85 km2 dengan jumlah penduduk 646.216 jiwa.

Pendahuluan berisi tentang latar belakang penelitian yang berkaitan dengan beberapa penelitian yang telah dilakukan). Gap Analysis dalam penelitian harus diperjelas yang terdiri dari : (i) State of the art (apa yang diketahui sejauh ini tentang topik yang diteliti, (ii) GAP (apa yang masih menjadi pertanyaan?, apa yang masih belum diketahui?), (iii) Novelty (apa kontribusi penelitian ini dalam menjawab pertanyaan?. Pada pendahuluan menggunakan sitasi dari buku atau jurnal. Untuk kutipan lebih dari duapenulis, pakai "et al". (Times New Roman 12 pt)

\section{METODE}

Jenis penelitian yang dilakukan adalah penelitian case control artinya sekelompok kasus (yakni pasien yang menderita efek atau penyakit) dibandingkan dengan kelompok kontrol (yang tidak menderita efek atau penyakit) (Sastroasmoro dan Sofyan, 2011). Penelitian ini mengukur kebersihan mulut dan kondisi jaringan periodontal penderita periodontitis dan non periodontitis. Populasi dalam penelitian ini adalah penderita periodontitis pada pengunjung Puskesmas Kota Tasikmalaya. Sampel dalam penelitian ini adalah penderita periodontitis yang berkunjung ke Puskesmas di Kota Tasikmalaya. Jumlah sampel pada penelitian ini adalah 40 orang penderita periodontitis dan 40 orang non periodontitis di Puskesmas Kota Tasikmalaya. Kriteria inklusi pengambilan sampel antara lain : 1) pasien penderita periodontitis dan non periodontitis yang terdaftar sebagai pengunjung Puskesmas Kota Tasikmalaya ; 2) bersedia menjadi responden ; 3) mempunyai gigi. Data yang digunakan dalam penelitian ini adalah data primer dan data sekunder, yaitu sebagai berikut : Data primer adalah data yang diambil langsung dari responden yaitu hasil pemeriksaankebersihan mulut dan kondisi jaringan periodontal. Data sekunder adalah data yang diperoleh dari data laporan penyakit tidak menular di wilayah kerja Puskesmas Kota Tasikmalaya. Analisis data pada penelitian ini dengan menggunakan uji statistik $C h i$ Square.

\section{HASIL DAN PEMBAHASAN}

Penelitian tentang kondisi kebersihan mulut dan jaringan periodontal pada pasien di Puskesmas Kawalu, Puskesmas Bantar, Puskesmas Sukalaksana dan Puskesmas Indihiang Kota Tasikmalaya, dilaksanakan pada 80 responden (40 responden dengan periodontitis dan 40 responden non periodontitis). Karakteristik kondisi kebersihan mulut pada responden dideskripsikan pada tabel berikut : 
Tabel 1. Karakteristik Kondisi Kebersihan Mulut pada Responden

\begin{tabular}{llllll}
\hline NO. $\begin{array}{l}\text { Kebersihan } \\
\text { Mulut }\end{array}$ & Periodontitis & \multicolumn{2}{l}{ Non Periodontitis } \\
\cline { 3 - 6 } & Frekuensi & $\begin{array}{l}\text { Persentase } \\
(\boldsymbol{\%})\end{array}$ & Frekuensi & $\begin{array}{l}\text { Persentase } \\
(\boldsymbol{\%})\end{array}$ \\
\hline 1. & Buruk & 37 & 92,5 & 20 & 50,0 \\
\hline 2. & Baik & 3 & 7,5 & 20 & 50,0 \\
\hline Jumlah & $\mathbf{4 0}$ & $\mathbf{1 0 0}$ & $\mathbf{4 0}$ & $\mathbf{1 0 0}$ \\
\hline
\end{tabular}

Berdasarkan tabel 1 diatas, dapat dilihat Responden periodontitis memiliki kebersihan mulut buruk sebanyak 37 orang $(92,5 \%)$, yang non periodontitis memiliki kebersihan mulut baik dan buruk sama banyaknya 20 rang (50\%). Kemudian Gula Darah Sewaktu pada responden periodontitis dan non periodontitis dideskripsikan pada tabel berikut

Tabel 2. Gula Darah Sewaktu pada Responden Periodontitis dan Non Periodontitis

\begin{tabular}{cccccc}
\hline NO. & $\begin{array}{c}\text { Gula Darah } \\
\text { Sewaktu }\end{array}$ & \multicolumn{2}{c}{ Periodontitis } & \multicolumn{2}{c}{ Non Periodontitis } \\
\cline { 3 - 6 } & Frekuensi & $\begin{array}{c}\text { Persentase } \\
(\mathbf{\%})\end{array}$ & Frekuensi & $\begin{array}{c}\text { Persentase } \\
(\%)\end{array}$ \\
\hline $1 . \quad \begin{array}{l}\text { Diabetes } \\
\text { Melitus }\end{array}$ & 17 & 42,5 & 6 & 15,0 \\
\hline 2. & $\begin{array}{l}\text { Non Diabetes } \\
\text { Melitus }\end{array}$ & 23 & 57,5 & 34 & 85,0 \\
\hline Jumlah & $\mathbf{4 0}$ & $\mathbf{1 0 0}$ & $\mathbf{4 0}$ & $\mathbf{1 0 0}$ \\
\hline
\end{tabular}

Berdasarkan tabel 2 diatas Sebanyak 17 orang responden periodontitis memiliki gula darah sewaktu lebih tinggi dari ukuran normal sebesar 17 orang $(42,5 \%)$, sedangkan yang non periodontitis memiliki gula darah sewaktu lebih tinggi dari ukuran normal sebanyak 6 orang $(15 \%)$. Kemudian Kebersihan mulut pada penderita diabetes mellitus disajikan pada tabel berikut :

Tabel 3. Kebersihan Mulut pada Penderita Diabetes Melitus

\begin{tabular}{|c|c|c|c|}
\hline No. & Kriteria Kebersihan Mulut & Frekuensi & $\begin{array}{c}\text { Persentase } \\
(\%)\end{array}$ \\
\hline 1. & Baik & 6 & 26,09 \\
\hline 2. & Buruk & 17 & 73,91 \\
\hline & Jumlah & 23 & 100,0 \\
\hline
\end{tabular}

Berdasarkan tabel 3 diatas Mayoritas kebersihan mulut pada penderita diabetes mellitus memiliki kriteria buruk sebanyak 17 orang $(73,91 \%)$. Kemudian Kebersihan mulut pada non diabetes mellitus disajikan pada tabel berikut : 
Home page: http://ejurnal.poltekkestasikmalaya.ac.id/index.php/jikg/index

Tabel 4. Kebersihan Mulut pada Non Diabetes Melitus

\begin{tabular}{|c|c|c|c|}
\hline No. & Kriteria Kebersihan Mulut & Frekuensi & $\begin{array}{c}\text { Persentase } \\
(\%)\end{array}$ \\
\hline 1. & Baik & 17 & 29,82 \\
\hline 2. & Buruk & 40 & 70,18 \\
\hline & Jumlah & 57 & 100,0 \\
\hline
\end{tabular}

Berdasarkan tabel 4 diatas Kebersihan mulut pada non diabetes mellitus mayoritas memiliki kriteria buruk 40 orang (70,18\%). Kemudian Analisa yang digunakan adalah $C h i$ Square dengan taraf signifikansi 5\%, hasilnya disajikan pada tabel berikut:

Tabel 5. Hasil Analisa Data

\begin{tabular}{lcc}
\hline \multicolumn{1}{c}{ Variabel/Diabetes } & $\boldsymbol{p}$ value & Keterangan \\
\hline Kebersihan Mulut & 0,738 & Tidak ada perbedaan \\
\hline Kondisi Jaringan Periodontal & 0,007 & Ada perbedaan \\
\hline
\end{tabular}

Berdasarkan tabel 5 diatas Hasil analisis menunjukkan bahwa tidak ada perbedaan kebersihan mulut pada penderita diabetes mellitus dengan non diabetes mellitus, serta terdapat perbedaan kondisi jaringan periodontal pada penderita diabetes mellitus dengan non diabetes mellitus. Kemudian Hasil analisis faktor risiko terjadinya periodontitis pada penderita diabetes mellitus disajikan pada tabel berikut:

Tabel 6. Hasil Analisis Data (Odd Ratio)

\begin{tabular}{cc}
\hline Variabel & Nilai Odd Ratio \\
\hline Diabetes/Non Diabetes & 4,188 \\
\hline
\end{tabular}

Tabel 6 diatas Hasil analisis menunjukkan bahwa penderita diabetes mellitus dapat Mengalami risiko periodontitis 4 kali dibandingkan non diabetes mellitus. Berdasarkan hasil penelitian menunjukkan tidak ada perbedaan kebersihan mulut pada penderita diabetes mellitus dan non diabetes mellitus, data menunjukkan mayoritas kebersihan gigi yang buruk dari kedua kelompok tersebut. Sejalan dengan penelitian ini bahwa di dua Rumah Sakit Yordania bahwa tidak terdapat perbedaan indeks plak (kebersihan mulut) yang signifikan antara penderita diabetes mellitus dan non diabetes mellitus. Hasil penelitian di Puskesmas Kota Tasikmalaya kemungkinan disebabkan kurang adanya pelihara diri, karena sebagian besar dari responden berpendidikan SD dan SMP sebanyak 62,5\%. Pendidikan bertalian erat dengan kemudahan memperoleh informasi yang diperlukan, baik melalui media cetak, radio, televisi maupun yang langsung diberikan oleh orang lain yang berkepentingan. Pada umumnya semakin tinggi pendidikan seseorang, semakin mudah memperoleh informasi misalnya hal-hal yang menunjang kesehatan (Notoatmodjo, 2010).

Terdapat perbedaan kondisi jaringan periodontal pada penderita diabetes mellitus dan non diabetes mellitus $(p=0,007)$. Kelompok diabetes mellitus memiliki risiko mengalami periodontitis 4 kali dibandingkan non diabetes mellitus $(\mathrm{OR}=4,188)$. Hasil penelitian ini sejalan dengan penelitian Rikawarastuti (2015) menunjukkan bahwa pada kelompok diabetes mellitus lebih berisiko 3,505 kali mengalami keparahan jaringan periodontal dibandingkan pada kelompok non diabetes mellitus. Berdasarkan hasil penelitian di 
Puskesmas Kota Tasikmalaya ditemukan penderita diabetes mellitus sebanyak 17 orang $(42,5 \%)$ mengalami periodontitis $(42,5 \%)$. Diabetes mellitus dapat menimbulkan komplikasi kesehatan umum maupun kesehatan rongga mulut, dari banyaknya komplikasi di rongga mulut, periodontitis merupakan komplikasi yang sering terjadi. Pada penelitian epidemiologi menunjukkan bahwa pada penderita diabetes mellitus risiko untuk terjadinya attachment loss dan alveolar bone loss tiga kali lebih besar daripada yang tidak mengalami diabetes mellitus. Insidensi periodontitis meningkat dan dapat menjadi lebih parah pada pasien yang mengalami diabetes mellitus. Berdasarkan hasil penelitian bahwa lamanya menderita diabetes mellitus ( \pm 2 tahun atau lebih) menunjukkan keparahan periodontitis (rata-rata memiliki poket dalam). Apabila periodontitis ini dirawat dengan terapi inisial yaitu scaling dan root planning maka dapat membantu penderita diabetes mellitus dalam mengontrol gula darah. Sebaliknya apabila periodontitis ini tidak dirawat maka akan mempersulit kontrol glukosa darah dan memperparah periodontitis bahkan menyebabkan hilangnya gigi.

\section{KESIMPULAN}

Berdasarkan hasil penelitian tentang "Kebersihan Mulut dan Kondisi Jaringan Periodontal Penderita Diabetes Melitus di Puskesmas Kota Tasikmalaya", dapat disimpulkan sebagai berikut: 1) Tidak ada perbedaan kebersihan mulut penderita diabetes mellitus dan non diabetes mellitus; 2) Ada perbedaan kondisi jaringan periodontal pada penderita diabetes mellitus dan non diabetes mellitus (Odd Ratio $=4$, artinya pada penderita diabetes mellitus memiliki risiko mengalami periodontitis sebesar 4 kali dibandingkan non diabetes mellitus)

\section{DAFTAR PUSTAKA}

Amerongen, AVN., 1991, Ludah dan Kelenjar Ludah : Arti Bagi Kesehatan Gigi, Jogjakarta:Gadjah Mada University Press, hal: 1-42

Ayu Lely, S., 2009, Artikel Pengaruh Kadar Gula Darah yang Terkontrol Terhadap Penurunan Derajat Kegoyahan Gigi Penderita Diabetes Mellitus di RS Persahabatan Jakarta, Badan Litbangkes: Jakarta

Budiarto, 2003, "Biostatistika: Untuk Kedokteran dan Kesehatan Masyarakat". EGC: Jakarta

Carranza, F.A., 2006,Clinical Periodontology, an HBJ International Edition, Philadelphia: WB Saunders Company, hal: 462-5

Daliemunthe, 2003, Hubungan Timbal Balik antara Periodontitis dengan Diabetes Mellitus, Dentika J Dent

Departemen Kesehatan R.I., 2007, “Pedoman Surveilans Epidemiologi Diabetes Melitus”, Direktorat Jendral PP \& PL: Jakarta

Gustaviani, Reno, 2006,Diagnosis dan Klasifikasi Diabetes Melitus. Dalam: Perhimpunan Dokter Spesialis Penyakit Dalam (PAPDI), Buku Ajar Ilmu Penyakit Dalam. Edisi IV. Jakarta: Pusat Penerbitan Departemen Ilmu Penyakit Dalam FK UI, hal: 1857

Johnson, M., 2005,Diabetes: Terapi dan Pencegahannya, cetakan 3, Bandung: Indonesia Publishing House, hal: 36-40

Kementerian Kesehatan RI, 2011, Surat Keputusan Menteri Kesehatan RI No. 021/Menkes/SK/I/2011 tentang Rencana Strategi Kementerian Kesehatan Tahun 2010 - 2014, Kemenkes RI, Jakarta

2012, Undang-undang Republik Indonesia Nomor 36 Tahun 2009, Badan Pengembangan dan Pemberdayaan SDM Kesehatan: Jakarta. 
2012, Pedoman Paket Dasar Pelayanan Kesehatan Gigi dan Mulut di Puskesmas, Kemenkes RI: Jakarta. Hal 1, 3, 23

, 2012, Rencana Program Pelayanan Kesehatan Gigi dan Mulut 2011 - 2025, Sudit Pelayanan Kesehatan Gigi, Jakarta

2014, Pusat Data dan Informasi Kementerian Kesehatan RI, Kemenkes RI: Jakarta. Hal 1

Manson, J. D., Eley, B. M.; 1993. Buku Ajar Periodonti (Outline of Periodontics). Alih bahasa: drg. Anastasia S. Editor: drg. Susianti K. 2nd ed. Jakarta: Hipokrates

Matthew, DC., 2002, The Relationship Between Diabetes and Periodontal disease, J. Can Dent Assoc; 68 (3) 161-4

Prapti, 2006, Tanaman Obat untuk Mengatasi Diabetes Mellitus, Agromedia Pustaka: Jakarta

Putri, M.H., dkk., 2010, Ilmu Pencegahan Penyakit Jaringan Keras dan Jaringan Pendukung Gigi, CV EGC: Jakarta. Hal 1, 56-59, 91, 99, 107-108, 112-118

Rikawarastuti, dkk., 2015, Diabetes Melitus dan Tingkat Keparahan Jaringan Periodontal, Jurnal Kesehatan Masyarakat Nasional, Vol. 9, Politeknik Kesehatan Jakarta I, Jakarta

Santosa, 2014, Sembuh Total Diabetes \& Hipertensi dengan Ramuan Herbal Ajaib, Pinang Merah: Jakarta

Sari, R, dkk., 2017. Prevalensi Periodontitis pada Pasien Diabetes Melitus Studi Observasional di Poliklinik Penyakit Dalam RSUP. Dr. Sardjito, Majalah Kedokteran Gigi Indonesia, Jurnal, Universitas Gadjah Mada, Yogyakarta

Sastroasmoro dan Sofyan, 2011, Dasar-dasar Metode Penelitian Klinis, Sagung Seto, Jakarta

Soegondo, dkk., 2007, Diagnosis dan Klasifikasi Diabetes Melitus Terkini dalam Penatalaksanaan Diabetes Melitus Terpadu, Balai Penerbit FKUI: Jakarta, hal:1718

Suyono, 2002,Kecenderungan Peningkatan Jumlah Pasien Diabetes, Jakarta: FKUI

Suyono, et al., 2006,Derajat Keasaman Air Ludah pada Penderita Diabetes, Cermin Dunia Kedokteran, No.150: 36

Vernino, A., 2005, Etiologi Penyakit Periodontal dalam silabus Periodonti, EGC, Jakarta

World Health Organization, 2015, Diabetes Fact and Numbers 2015 